\title{
The Effect of Light and Medium on Secondary Metabolite Production in Callus Culture of Kaemferia galanga Linn
}

\author{
Anis Shofiyani \\ Universitas Muhammadiyah Purwokerto \\ AnisShofyani@ump.ac.id, shofiyanianis@gmail.com
}

\begin{abstract}
This research investigated the effects of different media and environmental treatment (light and dark) on biomass and secondary metabolite production in callus culture of Kaemferia galanga. Environmental light had no significant effect on biomass callus. Media with sucrose $30 \mathrm{~g} / \mathrm{L}$ under light condition gave the highest biomass callus. Kaemferia galanga $\mathrm{L}$ callus contained alkaloids, flavonoids, saponins, steroids and ethyl p-methoxycinnamate (EPMC). Mean of EPMC content in bright environmental condition with sucrose concentration $20 \mathrm{~g} / \mathrm{L}$ medium gave average concentration value of ethyl p-methoxycinnamate $7,49 \mathrm{~g} / \mathrm{L}$ and with addition of sucrose 30 - $40 \mathrm{~g} / \mathrm{L}$ an increase of 2.31 to 2,39 times While the environmental treatment without light (dark) with a sucrose concentration of $20 \mathrm{~g} / \mathrm{L}$ medium of $3.21 \mathrm{~g} / \mathrm{L}$, with sucrose concentration added up to 30-40 $\mathrm{g} / \mathrm{L}$ there was an increase of ethyl p-methoxycinnamate levels ranging from 1.18 to 2.01 times
\end{abstract}

Keyword: sucrose, plant regulators, light, callus culture, Kaempferia galanga

\section{INTRODUCTION}

Kaemferia galanga $\mathrm{L}$ as a typical Indonesian plant is used as raw material of traditional medicine ( herbal medicine), fitofarmaka, food and beverage, spices and cosmetics [1]. Empirically Kaemferia galanga L functions as indigestion, cold, pectoral and stomach pain, antihypertensive and larvicidal activity [2] , diabetes mellitus [3], antinocyceptives and anti-inflammatory [4], anti-cancer and anti-monoamine oxidase [5], sedative activities [6], and anti-microbial [7] because it contains the active ingredient of saponins, flavonoids, phenols and essential oils [8].

In fact, the production of secondary metabolites from the $K$. galanga $\mathrm{L}$ rhizome for industrial needs is strongly influenced by the existence and growth of plants in the field which is certainly influenced by various environmental factors such as soil, nutrients, climate, pests and diseases. One other attempt that can be made to produce secondary metabolites is by in vitro culture technology [9]. Besides can be used for the conservation and propagation of plants [10], in vitro culture techniques can also be applied to the secondary metabolite production of $K$. galanga $\mathrm{L}$ with better results because in vitro cultured rhizome has an oil yield better, and it could be used for large-scale commercial propagation for sustainable use of essential oils [11].

Appropriate media composition as well as the use of carbon sources [12], types and concentrations of embedded growth regulators [13] and environmental conditions of cultures such as temperature and light [14] is a factor that determines the success of callus culture. The 2,4-D compound is a strong auxin that is often used singly to induce callus formation from various plant tissues [15]. A study conducted the addition of $1 \mathrm{mg} / 1$ of 2,4-Dichlorophenoxyacetic acid (2.4 D) in MS medium was able to induce callus formation in root, galvanized root or $K$. galanga L explant. Induction of callus in MS medium with addition of $1 \mathrm{mg} / \mathrm{L} 2,4 \mathrm{D}$ and $0.5 \mathrm{mg} / \mathrm{L}$ BAP also occurred in explant rhizome bud $K$. galanga $\mathrm{L}$ [16]. In This research has estabilished callus culture Kaemferia galanga $\mathrm{L}$ and investigated the effects of some media in dark and light environments on callus mass growth and production of ethyl p-metoxicinnamate.

\section{METHOD}

The basic medium used is MS /Murashige and Skoog, 1962 standards and growth regulators according to treatment. The acidity of the medium is adjusted to a $\mathrm{pH}$ value of 5.6 - 5.7. Provision explant done by taking a piece of meristem tissue from the rhizomatous buds of $K$. galanga that has been selected and sterilized. Explant further grown in a medium of callus induction with treatment of $2.4 \mathrm{D} 1 \mathrm{mg} / \mathrm{L}$.

Callus formed from callus induction media used as explants in this research. The tested treatment consisted of two factors: the first factor of light environment (light and dark) and the second factor was the composition of callus proliferation medium with a combination of sucrose concentration (20, 30 and $40 \mathrm{~g} \mathrm{/} \mathrm{L)} \mathrm{and}$ concentration of plant growth regulator (2,4-D 1 - $3 \mathrm{mg} /$ $\mathrm{L}$ and BAP 0-0.2 mg/L). All were randomly arranged in a Split Plot Design. Each treatment is placed in different environments ie in bright environments with $600-1000$ lux lighting using fluorescent lamps with 13 hours of illumination and dark environments.

Variable Observation and Data Analysis. Observations were made after callus was planted 8 weeks 
after inoculation. Observations include; fresh callus weight, callus dry weight, callus morphology and qualitative analysis of secondary metabolite content of $K$. galanga callus by TLC (thin layer chromatography). The data obtained were analyzed by analysis of variance (ANOVA) at 95\% confidence level, continued analysis with Least Significance Different (LSD) at $95 \%$ confidence level.

\section{RESULT}

\section{Callus growth}

Environmental treatment (light and dark) showed no significant effect on fresh weight of callus, but sucrose treatment on medium with combination of sucrose and plant growth regulator (2,4 D and BAP) showed no real effect. The treatment of sucrose $30 \mathrm{~g} / \mathrm{L}$ under light conditions gave the highest fresh weight of $5.51 \mathrm{~g}$ and decreased fresh weight of callus by $44.2 \%$ at $20 \mathrm{~g} / \mathrm{L}$ sucrose and $9.43 \%$ at $40 \mathrm{~g} / 1$ sucrose. The best dried weight of callus was found in the treatment of sucrose 30 $\mathrm{g} / \mathrm{L}$ weighing $0.57 \mathrm{~g}$ and a decrease of dry weight of callus on sucrose $20 \mathrm{~g} / \mathrm{L}$ by $54 \%$ and at $40 \mathrm{~g} / \mathrm{L}$ sucrose by $22.8 \%$.

The light effect on the formation of calli texture has no significant effect on the formation of callus color, the most profound weakness is obtained in the lightless environment treatment on the proliferation medium with sucrose concentration $30 \mathrm{~g} / \mathrm{L}$ medium combined with 2,4 D 2 ppm without BAP (D2B0) ie 3.67 (friable). Light affects the decrease in callus weakness rate of $5.67 \%$. Callus color that is formed has the tendency to form white to brownish-white color for treatment without light, while in light environment, color formation tends to look white to greenish white (figure 1).

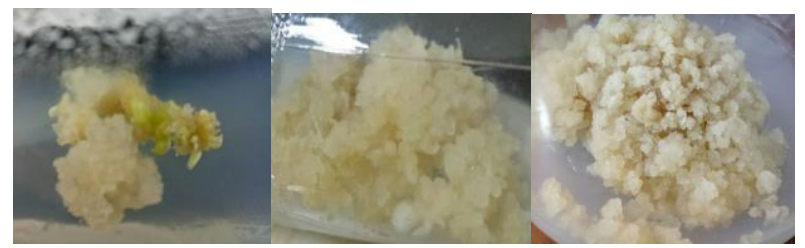

A. Growth and development of callus in without light (dark)

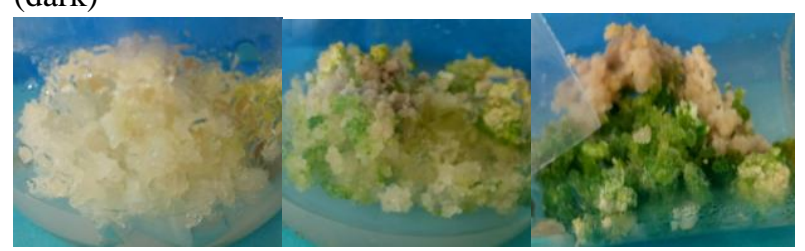

B. Growth and development of callus in with light

Figure 1. Growth and development of callus Kaemferia galanga on proliferative media without light (dark) and with light environmental treatment (light) of sucrose concentration and plant growth regulator (2.4 D and BAP).

Sucrose added in the callus proliferation medium serves as a source of energy required in the growth of callus cells, and the results show that the sucrose concentration of $30 \mathrm{~g} / \mathrm{L}-40 \mathrm{~g} / \mathrm{L}$ gives the best influence to the increase of fresh weight in callus of Basella rubra L [17], and Musa paradisiaca [18].
The use of growth regulators 2,4 D in callus proliferation medium is thought to be able to influence RNA metabolism that plays a role in controlling protein metabolism in cells that may be done on the transcription process of RNA molecules [19]. The treatment of $2 \mathrm{ppm}$ BAP and 2-4 ppm 2,4-D resulted in a greenish-yellow Callus with a friable structure at Musa paradisiaca [18].

The formation of green callus color in this research was due to the activity of chlorophyll production by the influence of light during callus grown and a certain amount of cytokinin concentration (Benzil aminopurin) added in callus proliferation medium spur development of chloroplast and chlorophyll synthesis [19]. Changes in brown color occurs as a result of the formation of phenol compounds in the callus [20].

Quantitative Analysis Content of Secondary Metabolite of Kaemferia galanga callus with Thin Layer Chromatography (TLC)

Qualitative and quantitative measurements with identification by using TLC Scaner on EPMC content showed all callus samples are capable of producing ethyl p-methoxycinnamate . Environmental treatment with light gives higher levels of ethyl p-methoxycinnamate than without the treatment of light (dark) environments. Mean of EPMC content in callus in light environmental condition with sucrose concentration $20 \mathrm{~g} / 1$ medium gave average concentration value of ethyl-pmethoxycinnamate $7,49 \mathrm{~g} / \mathrm{L}$ and with addition of sucrose $30-40 \mathrm{~g} / \mathrm{L}$ an increase of 2.31 to 2,39 times. While the environmental treatment without light (dark) with a sucrose concentration of $20 \mathrm{~g} / \mathrm{L}$ medium of 3.21 $\mathrm{g} / \mathrm{L}$, with sucrose concentration added up to 30-40 g / L there was an increase of ethyl p-methoxycinnamate levels ranging from 1.18 to 2.01 times. In line with the research on Gynura pseudochina the average contribution of the highest levels of anthocyanin was obtained by treatment of light intensity [21], saponin levels in Talinum paniculatum gaertn [22].

The effect of plant growth regulators, especially auxin in the synthesis of flavonoids, is to increase the action of the enzyme of phenylalanine ammonia liase (PAL) which produces cinnamic of phenylalanine [23] . The use of plant growth regulators has an effect on increasing the production of hypericin and pseudohypericin in in vitro cultures Hypericum hirsutum and Hypericum maculatum [24], phenolic acid in Ruta graveolens culture [25], and deoxyschizandrin and $\gamma$ scizandrin on Schisandra chinensis (Turcz) callus up to 9.0 to 20.6 fold with the addition of BA and NAA growth regulators [26].

\section{CONCLUSION}

The lightless environment gave the best callus of 3 (friable) The concentration of sucrose $30 \mathrm{~g} / \mathrm{L}$ medium gives the best callus growth effect on fresh weight of callus $6.78 \mathrm{~g}$, dry weight of callus $0.57 \mathrm{~g}$, callus texture with a level of weakness 3.17 (very friable) with a clear white to brownish white color. Ethanol extract of callus contains ethyl p-methoxycinnamate. The average EPMC 
content in callus in bright environmental conditions with the addition of sucrose $30-40 \mathrm{~g} / \mathrm{L}$ was increased by 2.31 to 2,39 times compared to the sucrose concentration of $20 \mathrm{~g} / \mathrm{L}$, while the environment treatment without light (dark) sucrose addition up to 30-40 g / L there was an increase of Ethyl p-methoxycinnamate levels ranging from 1.18 to 2.01 times.

\section{REFERENCES}

[1] Narayanaswamy R, Ismail IS, Intan Safinar Ismail., Cosmetic potential of Southeast Asian herbs: an overview. Phytochem Rev (2015) 14:419-428. DOI 10.1007/s11101-015-9396-2. 2015.

[2] Kim NJ,SG Byun, JE Cho, K Chung and YJ Ahn,. Larvicidal activity of Kaempferia galanga rhizome phenylpropanoids towards three mosquito species, Pest Management Science Pest Manag Sci 64 :857 $-862.2008$

[3] Jagadish PC, Raghu Chandrashekhar H, Vinod Kumar S, Latha KP. Potent selective cytotoxic activity of Kaempferia galanga rhizome against cancer cell cultures. International Journal of Pharma and Bio Sciences 2010; V1:1-5.

[4] Sulaiman, M.R., Zakaria, Z.A., Daud, I.A., Ng, F.N., Ng, Y.C., Hidayat, M.T., Antinociceptive and anti-inflammatory activities of the aqueous extract of Kaempferia galanga leaves in animal models. J. Nat. Med.62, 221-227 (15) Bhojwani SS and Razdan MK (1996), Plant Tissue Culture: Theory and Practice, A Revised Edition, elseivier, Amsterdam. 2008.

[5] Tewtrakul, S., Yuenyongsawad, S., Kummee, S., and Atsawajaruwan, L. Chemical Components and Biological Activities of Volatile Oil of Kaempferia galanga Linn. Songklanakarin Journal of Science and Technology.27(2):503-507. 2005.

[6] Huang, L., T. Yagura, and S. Che.,. Sedative activity of hexane extract of Keampferia galanga $L$. and its active compounds. J. Ethnopharmacol. 30: 123-125. 2008.

[7] Kochuthressia KP, Britto SJ, Jaseentha MO, Rini $\mathrm{R}$., In vitro antimicrobial evaluation of Kaempferia galanga L. rhizome extract. Am J Biotechnol Mol Sci.2(1):1-5. 2012.

[8] Umar MI, Asmawi MZB, Sadikun A, Altaf R, Iqbal MA., Phytochemistry and medicinal properties of Kaempferia galanga L. (Zingiberaceae) extracts. Afr J Pharm Pharmacol.5(14):1638-47. 2011.

[9] Kalpana M, Anbazhagan M. In vitro production of Kaempferia galanga (L.)-An endangered medicinal plant. J Phytology. 1:56-61. 2009.

[10] Rajasekharan, P.E., and S. Ganeshan., In Vitro regeneration and conservation of Kaemferia galanga L. J. Med. Aromat. Plant Sci. 24: 132-147 (24). Pi Y, K Jiang, R Hou, Y Gong, J Lin, X Sun, $\mathrm{K}$ Tang., 2010. Examination of amptothecin and 10hydroxycamptothecin in Camptotheca acuminata plant and cell culture, and the affected yields under several cell culture treatments. Biocell, 34(3): 139143. 2009.

[11] Sahoo S, Parida R, Singh S, Padhy RN, Nayak S.. Evaluation of yield, quality and antioxidant activity of essential oil of in vitro propagated Kaempferia galanga Linn. J Acute Dis 124 - 130. 2014

[12] Reza, B., Omid, K. and Mansour, G. Influence of Carbon Sources and Their Concentrations on Rooting and Hyperhydricity of Apple Rootstock MM.106. World Applied Sciences Journal.6(11):1513-1517.. 2009.

[13] Kavyashree R ,. An efficient in vitro protocol for clonal multiplication of Ginger - var. Varada, Indian Journal Biotechnology.Vol 8, July 2009, pp 328-331. 2009

[14] Yu KW, HN Murthy, EJ Hahn and KY Paek, Ginsenoside production by hairy root cultures of Panax ginseng : influence of temperature and light quality Biochemical Engineering Journal 23 (2005) 53-56. 2005.

[15] Garg L, N.N Bhandari, V Rani, and SS Bhojwani, Somatic embryogenesis and regeneration of triploid plants in endosperm cultures of Acacia nilotica. Plant Cell Reports 15:855-858. 1996.

[16] Kuen, TG. Mutasim, MK. Arvind B and Chan LK, Callus Induction and Cell line Establishment from Various Explant of Kaemferia galanga. International journal of Current research vol. 3, issue.12. pp. 01-04. 2011.

[17] Sitorus, E.N., Endah D.H., dan Nintya S. Induction of Callus Binahong (Basella rubra L.) In vitro on Murashige \& Skoog Media with Different Sukrosa Concentration.Bioma 13(1).. 2011.

[18] Marlin, Yulian, dan Hermansyah, Initiation of embryogenic callus formation of Banana 'Curup' male bud culture supplemented with sucrose, BAP, and 2,4-D. J. Agrivigor 11(2): 276-284, Mei Agustus 2012; ISSN 1412-2286 . 2012.

[19] Salisbury, F.B. and C.W. Ross. Plant Physiology, 4 th Edition, Wadsworth Publishing, Co. 1992.

[20] Abdullah, M.A., M. Ali, N.H. Marziah, dan A.B. Arrif, 1998. Establisment of cell suspension cultures of Morinda elliptica for the production of anthraquinoes. Plant Cell Tissue and Organ Culture 54: 173-182.

[21] Ariany, SP. N. Sahir, A.Syakur. Effect Of Light On The Growth Quantity And Content Of Anthocyanin Of Leaf Dewa (Gynura pseudochina ( L. ) DC ) In Vitro. e-J. Agrotekbis 1 (5) : 413 - 420, Desember 2013. 2013.

[22] Alwiyah, A., Y. S. W. Manuhara and E. S. W. Utami, Pengaruh intensitas cahaya terhadap biomassa dan kadar saponin kalus ginseng jawa (talinum paniculatum gaertn.) pada berbagai waktu kultur. Jurnal Ilmiah Biologi FST. vol. 3 / No. 1 / Published : 2015-01 ISSN 2303-3428,. 2015.

[23] Rahayu,B., Solikhatun dan Endang,A. Effect of 2.4Dichlorophenoxyacetic Acid (2,4-D) on Callus Growth and Flavonoid Content of Callus Culture 
Acalypha indica L. Biofarmasi. 1(1):1-6, Februari 2003, ISSN:1693-2242. 2002.

[24] Coste, A., Vlase, L., Halmagyi, A., Deliu, C., Coldea, G., Effects of plant growth regulators and elicitors on production of secondary metabolites in shoot cultures of Hypericum hirsutum and Hypericum maculatum. Plant Cell, Tissue and Organ Culture 106, 279-288. 2011.
[25] Ekiert, H., Szewczyk, A., Ku's, A., Free phenolic acids in Ruta graveolens L. in vitro culture. Pharmazie 64, 694-696. 2009.

[26] Szopa, A., and Ekiert, H., Production of deoxyschizandrin and _-schizandrin in shootdifferentiating and undifferentiating callus cultures of Schisandra chinensis (Turcz.) Baill. (Chinese magnolia vine) Journal of Biotechnology 165 (2013) 209-213. 2013. 